\title{
Faktor-Faktor yang Mempengaruhi Pola Aktivitas dan Pola Pesebaran Pedagang Kaki Lima (PKL) di Koridor Jalan Pejanggik, Kecamatan Cakranegara
}

\author{
* Ardi Yuniarman, Baiq Siti Noer Azima, Sri Apriani Puji Lestari \\ Teknik Perencanaan Wilayah dan Kota, Universitas Muhammadiyah Mataram \\ *Email:ardhi.yuniard@gmail.com
}

INFO ARTIKEL
Riwayat Artikel:
Diterima: 16-12-2019
Disetujui: 18-02-2020

Kata Kunci:

Faktor Mempengaruhi

Pola Aktifitas

Pola Pesebaran

Pedagang Kaki Lima

\begin{abstract}
ABSTRAK
Abstrak Koridor Jalan Pejanggik merupakan jalan kolektor 3 dengan tingkat kepadatan yang cukup tinggi di Kota Mataram dan merupakan kawasan ekonomi berupa perdagangan dan jasa/komersial. Tingkat kemenarikan kawasan ini secara ekonomi terlihat dengan banyaknya aktifitas ekonomi informal berupa Pedagang Kaki Lima (PKL.). kegiatan PKL memberikan dampak positif dan juga negatif terdapak fungsi dan aktifitas kawasan khususnya kawasan ekonomi Cakranegara. Tujuan penelitian ini yaitu untuk mengetahui faktor yang mempengaruhi pola aktivitas dan pola penyebaran PKL. Metode analisis yang digunakan berupa deskriptif kualitatif berdasarkan hasil wawancara, observasi, studi pustaka dan dokumentasi. Hasil analisa menunjukkan bahwa setiap aktivitas pedagang kaki lima dipengaruhi oleh hubungan langsung atau tidak langsung dengan aktivitas formal di koridor jalan tersebut serta aktivitas ini dipengaruhi oleh waktu berdagangnya. Adapun pola penyebarannya cenderung linier mengikuti pola jalan. Saran: Kegiatan PKL perlu diakomodasi sesuai dengan kapasitas dan kemampuan ruang jalan.
\end{abstract}

\begin{abstract}
The Pejanggik Road Corridor is a collector 3 road with a high density in Mataram City and is an economic zone in the form of trade and services / commercial. The level of attractiveness of this region is economically seen by the many informal economic activities in the form of street vendors (PKL.). PKL activities have both positive and negative impacts on the functions and activities of the region, especially the Cakranegara economic area. The purpose of this study is to determine the factors that influence the pattern of activity and patterns of distribution of street vendors. The analytical method used in the form of descriptive qualitative based on the results of interviews, observations, literature studies and documentation. The results of the analysis show that every street vendor's activity is influenced by direct or indirect relationship with formal activities on the road corridor and this activity is affected by the trading time. The distribution pattern tends to be linear, following the road pattern. Suggestion: The activities of street vendors need to be accommodated according to the capacity and ability of the road space.
\end{abstract}

\section{A. LATAR BELAKANG}

Peraturan Daerah Kota Mataram Nomor 10 Tahun 2015 tentang Pedagang Kaki Lima bahwa pedagang kaki lima yang selanjutnya disingkat PKL adalah pelaku usaha yang melakukan usaha perdagangan dengan menggunakan sarana usaha bergerak maupun tidak bergerak, menggunakan prasarana kota, fasilitas social, fasilitas umum, lahan, dan bangunan milik pemerintah dan/ atau swasta yang bersifat sementara/ tidak menetap. Berdasarkan Perda. Kota Mataram No.12 Tahun 2012 tentang Rencana Tata Ruang Wilayah (RTRW), Koridor Jalan Pejanggik merupakan jalan kolektor 3 dengan tingkat kepadatan yang cukup tinggi di Kota Mataram merupakan kawasan ekonomi diperuntukkan bagi perdagangan dan jasa / komersial. Tingkat kemenarikan kawasan ini secara ekonomi terlihat dengan banyaknya aktifitas ekonomi informal beru Pedagang Kaki Lima (PKL.) Adanya aktivitas perdagangan dan jasa / komersial pada Koridor Jalan Pejanggik ini memberikan dampak baik secara positif maupun negative terhadap fungsi kawasan. Dampak positif aktifitas PKL adalah peningkatan kegiatan perekonomian masyarakat secara informal karena memberikan peluang usaha. Sedangkan dampak negatif yang ditimbulkan dari kegiatan PKL adalah pemanfaatan ruang pedestrian sebagai area usaha PKL dan aktifitas parkir yang memanfaatkan badan jalan sebagai lahan parkir dan berdampak pada penyempitan ruang jalan sebagai akses pergerakan kendaraan bermotor.

Kegiatan PKL dalam pemanfaatan ruang disepanjang koridor Jalan Pejanggik memiliki karakteristik pemanfaatan yang berbeda-bedar. Hal ini terlihat dari waktu kegiatan, jenis usaha dan posisi 
perletakan lahan PKL tersebut. Perlakuan temapt dan pemilihan tempat usaha kegiatan PKL tersebut jelas sangat dipengaruhi oleh kondisi fisik maupun aktifitas yang terjadi disepanjang koridor Jalan Pejanggik Cakranegara. Hal ini juga dijelaskan bahwa aspek yang dilihat pengguna tidak hanya dari segi bentuknya saja tetapi dari aktivitas yang dilakukan oleh manusia di dalamnya (Rizky, 2015). Salah satu aktifitas di koridor jalan adalah aktifitas komersial.

\section{B. METODE PENELITIAN}

Pendekatan penelitian yang digunakan pada penelitian ini adalah pendekatan deskriptif kualitatif. Pengumpulan data dilakukan melalui observasi lapangan, dokumentasi dan wawancara terhadap responden terhadap Pola Aktifitas dan Pola Pesebaran kegiatan PKL berdasarkan Lokasi, Waktu, Jenis Sarana, Aglomerasi dan Aksesibilitas. Observasi dan wawancara ditujukan untuk memperoleh gambaran pemetaan terhadap pola aktivitas pedagang kaki lima dan pola penyebarannya. Metode analisis yang digunakan berupa deskriptif kualitatif berdasarkan hasil wawancara, observasi, studi pustaka dan dokumentasi.

\section{HASIL DAN PEMBAHASAN}

1. Lokasi Kegiatan Penelitian

Lokasi penelitian ini berada di koridor Jalan Pejanggik yang berada di kawasan ekonomi Cakranegara dan secara administrasi berada di garis batas antara Kelurahan Cakra Barat dan Kelurahan Cilinaya. Koridor Jalan Pejanggik ini memiliki panjang $1,3 \mathrm{~km}$ yang merupakan kawasan perdagangan dan jasa. Dengan batas administrasi wilayah perencanaan ialah sebagai berikut:

Utara : Jl. Kebudayaan (Kelurahan Cakra Barat)

Barat : Jl. Pejanggik dan Jl. Bung Hatta

Selatan : Jl. Panca Usaha (Kelurahan Cilinaya)

Timur : Jl. A.A. Gede Ngurah dan Jl. Selaparang

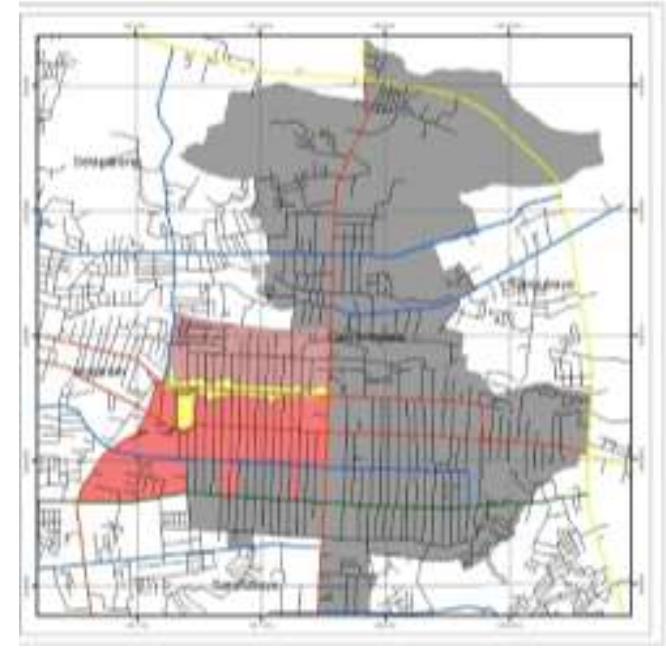

Gambar 1.

Peta Deliniasi Koridor Jalan Pejanggik dan Posisi Lokasi Kegiatan.
Menurut Moughtin (Shintia Feiby, 2018) suatu koridor biasanya pada sisi kiri kanannya telah ditumbuhi bangunan-bangunan yang berderet memanjang di sepanjang ruas jalan tersebut. Keberadaan bangunan-bangunan tersebut secara langsung maupun tidak langsung akan menampilkan kualitas fisik ruang pada lingkungan tersebut. Sedangkan Zahnd (Shintia Feiby, 2018), menyebutkan bahwa koridor dibentuk oleh dua deretan massa (bangunan atau pohon) yang membentuk sebuah ruang untuk menghubungkan dua kawasan atau wilayah kota secara netral. Dengan kata lain, koridor merupakan ruang berupa plasa, jalan atau lorong memanjang yang terbentuk oleh deretan bangunan, pohon, atau perabot jalan untuk menghubungkan dua kawasan dan menampilkan kualitas fisik ruang tersebut.

2. Pola Aktivitas dan Pola Penyebaran PKL

a. Pola Aktivitas

Pola Aktifitas Menurut Mc Gee dan Yeung (Widjajanti, 2015) pola aktivitas PKL sangat dipengaruhi oleh aktivitas sektor formal dalam menjaring konsumennya. Lokasi PKL sangat dipengaruhi oleh hubungan langsung dan tidak langsung dengan berbagai kegiatan formal dan kegiatan informal atau hubungan PKL dengan konsumennya dengan mepertimbangkan Lokasi bedagang, Waktu Berdagang dan Jenis Dagangan.

1) Lokasi Berdagang

Berdasarkan Gambar 2 terlihat bahwa lokasi yang paling diminati oleh PKL yaitu berada berdekatan dengan pusat kegiatan dari masingmasing retail toko tersebut di sekitarnya. Lokasi berdagang juga terlihat berkosentrasi penuh pada area yang relatif teduh atau terlindungi dari sengatan mahahari seperti penempatan PKL dibawah pohon atau di emper bangunan pertokoan yang memiliki atap atau kanopi bangunan.

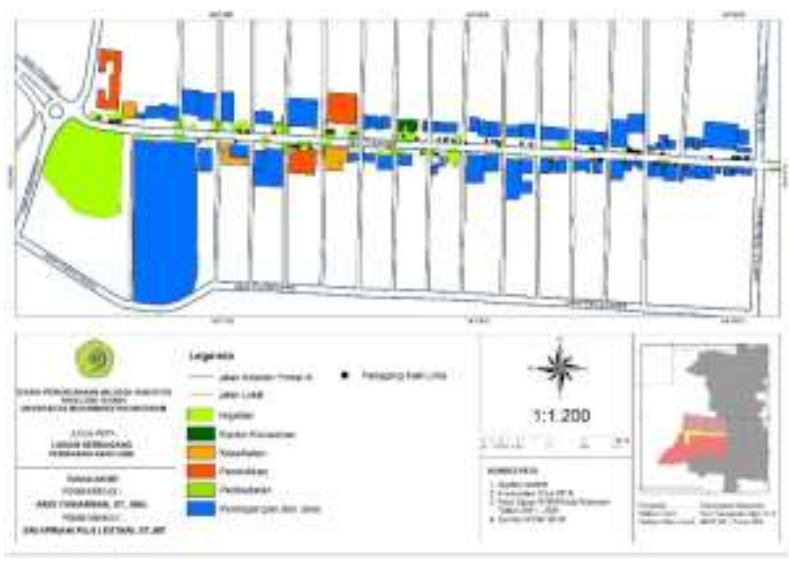

Gambar 2.

Peta Lokasi Berdagang PKL di Koridor Jalan Pejanggik Kecamatan Cakranegara. 
2) Waktu Berdagang

Berdasarkan waktu kegiatan PKL terbagai atas 2 (dua) kelompok hari dalam seminggu yaitu hari kerja (senen sampai jumat) dan akhir pekan (hari sabtu dan minggu). Dari kelompok hari tersebut terbagi atas kelompok waktu jam yaitu pagi sampai dengan sore (jam 07.00 - 15.00) dan sore sampai dengan malam hari (15.00 - 00.00).

Pada Gambar 3, waktu berdagang PKL sangat dipengaruhi oleh waktu kegiatan pada kawasan disepanang koridor Jalan Pejanggik dan aktifitas di masing-masing retail toko tersebut. Pada waltu Pagi sampai dengan sore terlihat pemusatan kegiatan PKL terlihat di area dimana tingkat intesitas pengunjung dan aktifitas perdagangan di toko tersebut tinggi.

Makin tinggi tingkat pengunjung maka makin tinggi pula aktifitas PKL terjadi disekitarnya dengan syarat bahwa area tersebut cukup teduh terhadap teriknya sinar matahari. Sedangkan pada sore hingga malam hari (lihat Gambar 4), kegiatan PKL terlihat tidak memusat pada area tertentu saja, akan tetapi kegiatan PKLnya sudah mulai menyebar. Penyebaran kegiatan PKL tetap masih cukup tinggi diarea dimana tingkat konsentrasi pengunjung masih tinggi, seperti kawasan Rumah Sakit Risa, dan area sekita Mataram Mall dan Ruby Swalayan.

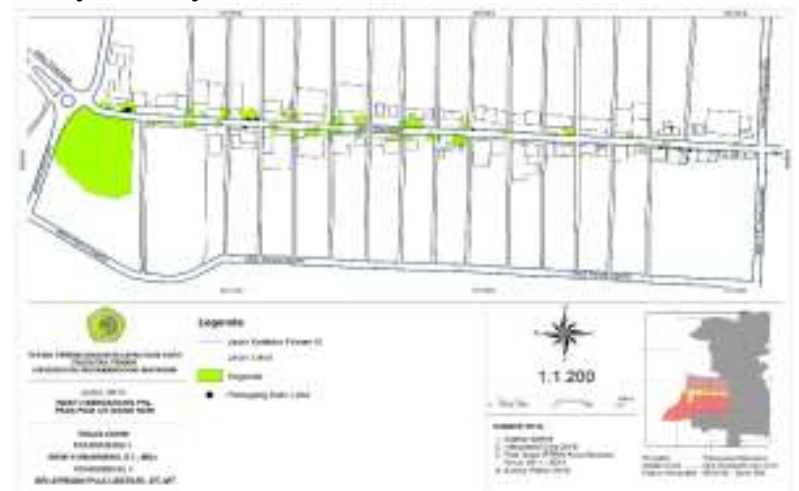

Gambar 3.

Peta Waktu Berdagang PKL Pada Pagi Hingga Siang Hari di Koridor Jalan Pejanggik Kecamatan Cakranegara
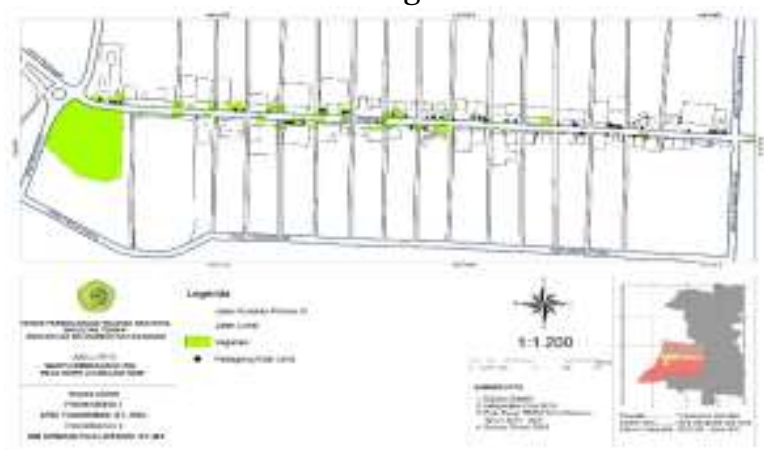

Gambar 4.

Peta Waktu Berdagang PKL Pada Sore Hingga Malam Hari di Koridor Jalan Pejanggik Kecamatan

Cakranegara
3) Jenis Dagangan dan Sarana Berdagang

Berdasrkan Gambar 5 dan 6 menunjukan 3 (tiga) jenis kelompok Jenis Dagangan yaitu Pedagang Aksesoris dan peralatan, Pedagang Warung Makanan dan Kios Serba ada (menjual makanan ringan, rokok dan sejenisnya). Dari ketiga kegiatan jenis Dagangan PKL tersebut terlihat bahwa konsentrasi kegiatan usaha trsebut memusat pada area-area diamana tingkat kegiatan pengunjung cukup tinggi. Disamping itu, jenis usaha dagangan PKL juga menyesuaikan dengan lokasi atau tempat jenis toko tersbut menjual barangnya. Seperti, terdapat toko yang menjual Alat ulis maka PKL yang muncul disekitarnya adalah usaha alat tulis jg termasuk Poster-poster.

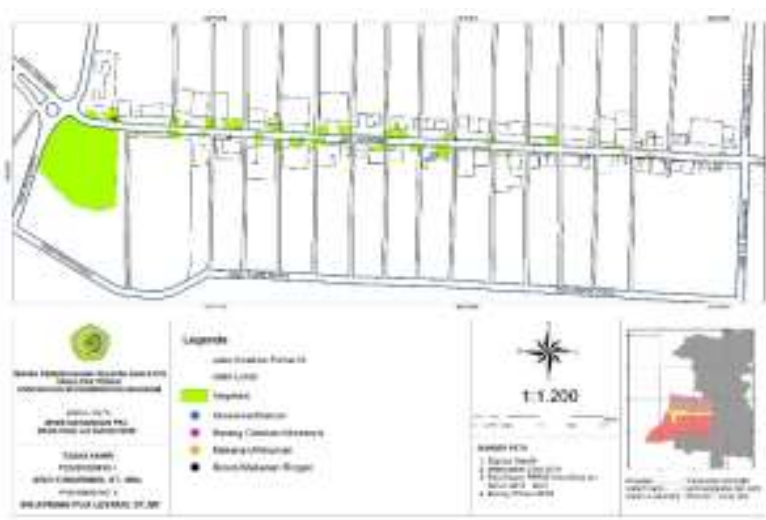

Gambar 5 .

Peta Jenis Dagangan PKL Pada Waktu Pagi Hingga Siang Hari di Koridor Jalan Pejanggik Kecamatan Cakranegara

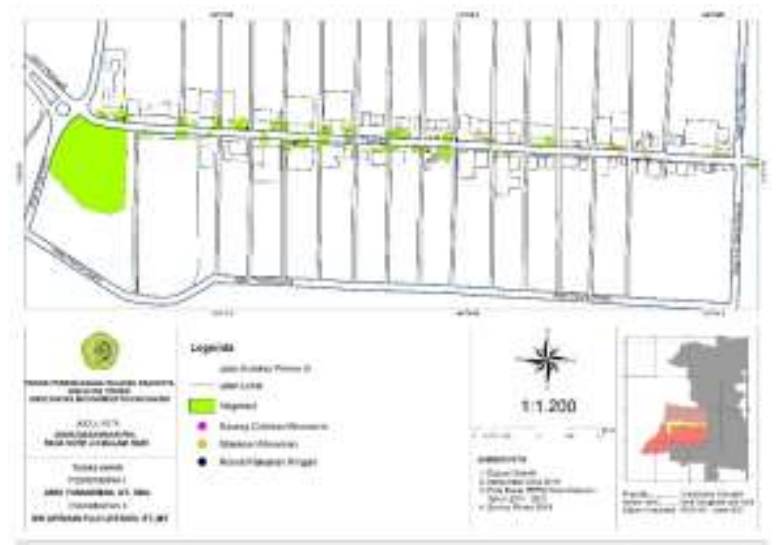

Gambar 6.

Peta Jenis Dagangan PKL Pada Waktu Sore Hingga Malam Hari di Koridor Jalan Pejanggik Kecamatan Cakranegara

Adapun jenis sarana dagangan yang digunakan para pedagang kaki lima di koridor Jalan Pejanggik, seperti gerobak, tenda (warung semi permanen), meja, rak, lesehan, gelaran dan kereta dorong merupakan sarana berdagang yang mudah dan iaplikasikan dan digunakan untuk menggelar dagangannya, sehingga mudah untuk dikemas dan dipindahkan serta perletakannya tidak 
membutuhkan space banyak serta mudah terlihat oleh para pengunjung.

Jenis-jenis sarana dagangan yang digunakan tersebut mudah untuk dibongkar pasang dan dipindahkan untuk disimpan/dibawa pulang oleh pedagang. Jenis dagangan yang menggunakan gerobak didominasi oleh kios-kios kecil yang menjajakan dagangan beruka makan kecil dan juga rokok serta alat-alat keperluan lainnya. Sedangkan pkl yang menggunakan tenda pada umumnya menjajakan jenis makan-makan yang relatif berat seperti Lalapan dan sejenisnya. Penggunaan atap atau kanopi dari beberapa jenis lapak juga mempengari terhadap tersedianya vegetasi penedug atau tidak atau tersedianya kanopi pada bangunan tersebut atau tidak.

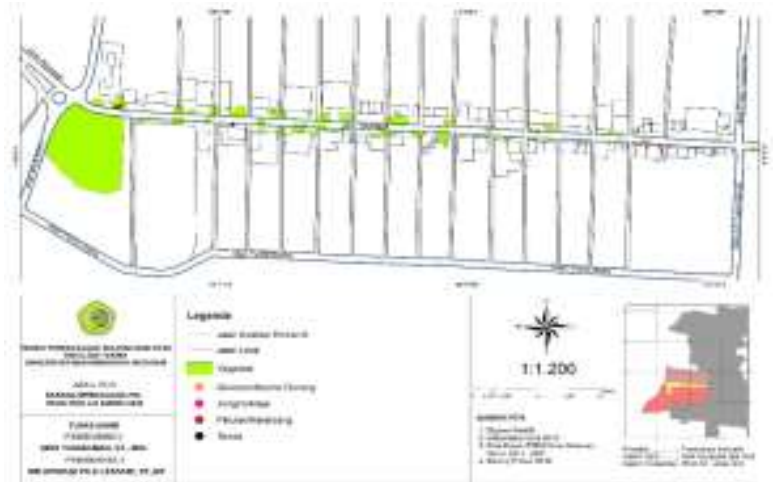

Gambar 7.

Sarana Berdagang PKL Pada Waktu Pagi Hingga Siang Hari di Koridor Jalan Pejanggik Kecamatan Cakranegara

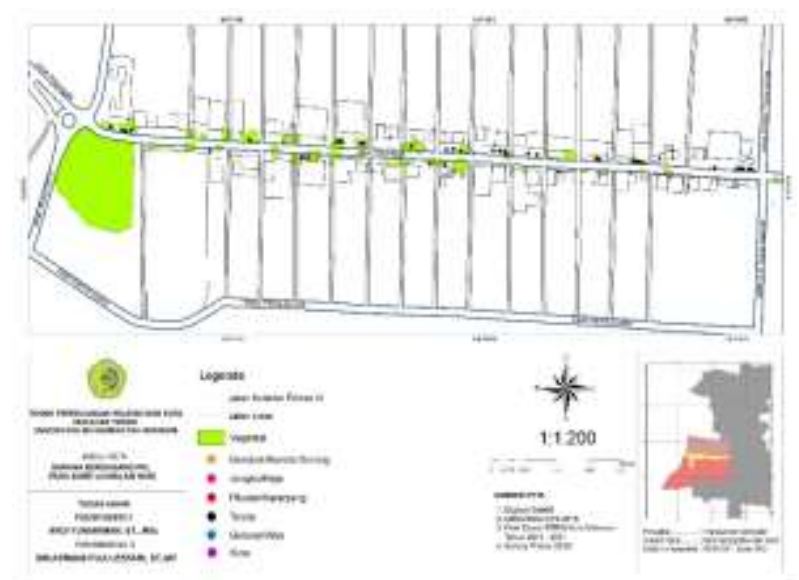

Gambar 8.

Sarana Berdagang PKL Pada Waktu Sore Hingga Malam Hari di Koridor Jalan Pejanggik Kecamatan Cakranegara

\section{b. Pola Penyebaran}

Menurut Mc Gee dan Yeung (Widjajanti, 2015) pola penyebaran PKL dipengaruhi oleh aglomerasi dan aksesibilitas. Pola penyebaran PKL ini terjadi di mulai dari pintu masuk koridor Jalan Pejanggik hingga pintu keluar koridor jalan utama. Kegiata pedagang PKL ini berderet memanjang mengikuti pola jalan. Hal ini terlihat bahwa pola pesebaran aktifitas PKL terlihat linier disepanjang koridor Jalan Pejanggik Cakranegara sebagai pusat kegiatan ekonomi di Kota Mataram.

Dari memanjangnya kegiatan PKL disepanjang koridor jalan, terjadi beberapa kelompok pedagang. Hal ini disebabkan adanya kemenarikan lokasi terhadap aktifitas perdagangan yang terjadi di lokasi tersbesut, seperti area pertokoan alat tulis dan olah raga didominasi PKL yang berdagang dengan jenis usaha yang mendukung kegiatan perdagangan di toko tersebut. Pola pesebaran ini disebut sebagai pola aglomerasi.

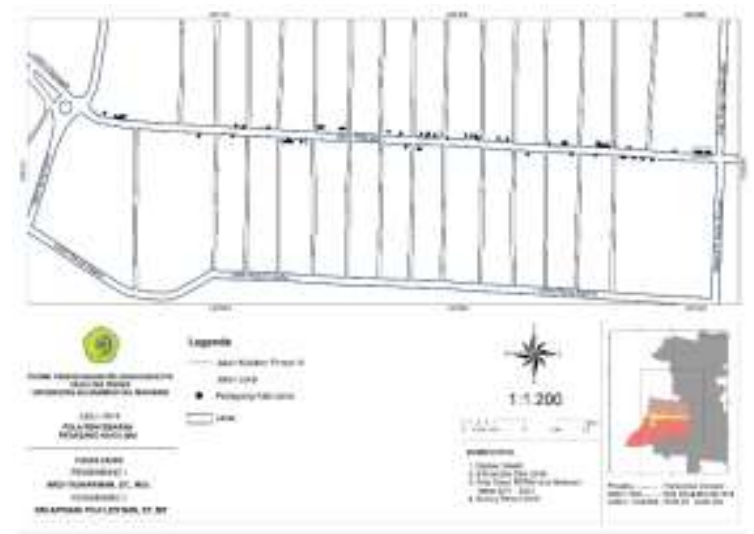

Gambar 9.

Peta Pola Penyebaran PKL di Koridor Jalan Pejanggik Kecamatan Cakranegara

\section{SIMPULAN DAN SARAN}

1. Simpulan

a. Pola aktivitas PKL tidak terlepas dari pengaruh hubungan langsung dan tidak langsung dengan berbagai kegiatan yang terjadi dikawasan tersebut dalam pemanfaatan bangunan sebagai tempat usaha baik formal mapun kegiatan informal.

b. Jenis dan bentuk kegiatan PKL dipengaruhi oleh waktu kegiatan dimana pada kegiatan waktu kerja didominasi usaha-usaha PKL sesuai aktifyas perdagangan yang terjadi diarea lokasi PKL. Sedangkan apda malam hari terjadi peningkatan jumlah PKL tetapi jenis kegiatan PKL didominasi usaha makanan.

c. Pada siang hari, penentuan lokasi berdagang juga dipengaruhi kondisi fisik kegiatan seperti adanya vegetasi peneduh dan kanopi bangunan yang mempu menghalang sinar matahari.

d. Keterpusatan kegiatan perdagangan dikawasan koridor jalan Pejanggik membuat menumpuknya kegiatan PKL tersebut.

e. Space yang kurang untuk penempatan lapak PKL menajdikan Pedestrian sebagai ekspansi tempat usaha.

2. Saran

a. Kegiatan PKL perlu diakomodasi sesuai dengan kapasitas dan kemampuan ruang jalan. 
b. Penentuan jenis dan bentuk usaha dalam pemanfaatan gedung pertokoan yang akan mempengaruhi munculnya PKL dan keterpusatan PKL yang berdampak pada kemacetan dalam kegiatan transportasi.

c. Memberikan space ruang untuk kegiatan PKL sehingga tidam mengambil ruang badan jalan dan trotoar.

d. Memberikan arahan terhadap desain lapak PKL sehingga lebih menarik dan tertata dan dapat m,eningkatkan kemenarikan kawasan sebagai kawasan ekonomi.

\section{DAFTAR PUSTAKA}

[1] Anonim, (2011). Peraturan Daerah Kota Mataram Nomor: 12 Tahun 2012 "Tentang Rencana Tata Ruang Wilayah Kota Mataram”.Bappeda Kota Mataram.

[2] Anonim. (2015). Perda Kota Mataram Nomor 10 Tahun 2015 "Tentang Pedagang Kaki Lima. Mataram": BPPK Kota Mataram.

[3] Rizky, S. B. (2015). Pengaruh Kegiatan Komersil Terhadap Kinerja Jalan:Studi Kasus Koridor Jalan Yos Sudarso. Jurnal Arsitektur, Vol 30, 4.

[4] Shintia Feiby, S. d. (2018). Analisis Perubahan Fisik Kawasan Koridor Jalan Boulevard II Pasca Operasi Jalan. Jurnal Spasial, 4.

[5] Widjajanti, R. (2015). "Karakteristik Aktivitas Pedagang Kaki Lima Pada Kawasan Komersil di Pusat Kota”, Jurnal Teknik Vol 30, 6. 2015. 